International Journal of Business Management and Economic Review

Vol. 4, No. 04; 2021

ISSN: 2581-4664

\title{
THE IMPACT OF THE SOCIAL RESPONSIBILITY ADOPTION BY BANKS ON THEIR OUTCOMES: AN APPLIED STUDY ON SOME PUBLIC AND PRIVATE BANKS IN WASIT GOVERNORATE / IRAQ
}

\author{
Kamal Alwan Muhaisin \\ Lecturer at Dept. of Business Administration University of Wasit,Wasit, Iraq \\ http://doi.org/10.35409/IJBMER.2021.3299
}

\begin{abstract}
This paper aims to explore the impact social responsibility adoption by banks on their different types of outcomes achieved during the year. Four kinds of social responsibility toward: environment, Society, education and learning, and culture and arts wear tested to see its impacts on the bank outcomes: government and owners, employees, services offered, and bank reputation. A model was developed based on other studies and hypotheses were formulated. Four banks were chosen to be the sample in this paper, two of the banks are public ones meanwhile the others are private.

The sample size consisted of 50 employees whom were reached through a questionnaire, all of them answered it completely, so all them used in the analysis. The results showed that the employees indicated that social responsibility practices and activities are very important factors affecting outcomes, The improvement achieved on the outcomes should encouraged banks continuing that activities. Significant positive relationships were discovered and statistically proven between both variables. The paper's main recommendation is advising the studied banks to take in account in their future plans the detailed study of more social activities and support to the community and to enlarge the sample and include customers in that study.
\end{abstract}

Keyword: Social Responsibility; Social Performance; Bank outcomes; Environment; Banks' Performance.

\section{INTRODUCTION}

After 2003 Iraq had seen big change in all aspect of life; one of the main changes was in the banking industry. A high number of private banks opened their doors for customers to offer their services successfully contribute to the Iraqi economic progress. As a result, the government and the society start to pressure to ask for social and philanthropic activities that must be offered by banks and some of the profits should be directed to help and to support many social and cultural activities like environment protection, education, arts, and cultural issues. So, some new opinions begin today be diffused about the integration of ethical fundamentals in the banking environment. Social responsibility was explained as the voluntary incorporation of social and environmental interests into the organization's decision-making process (Soana, 2011) This notion is widely applied banking environment work nowadays, it is recognized as an effective 


\section{International Journal of Business Management and Economic Review}

Vol. 4, No. 04; 2021

ISSN: 2581-4664

instrument to reflect a positive image and bring newer clientsandcourage people and businesses to deal with the banks.

In their study, Mandina et al. (2014) tested the efficiency of CSR in building and consolidating the total image, emphasizing philanthropic activities and they conclude that adopting this kind of practices and activities improved significantly the banks reputation and make the relationship with the community stronger. Participating and supporting initiatives that protect the environment, reducing the pollution, contributing to education improvement, and helping effectively in backing hospitals during the Covid 19 pandemic, all that give banks new image and improve the wide picture about their role in the life, especially those private one.

This paper is testing and evaluating the social responsibility activities that support and improve the different aspects of life of society, create advantages for customers and community in total. It consists applied of four parts. In the first part, the paper reviews some literature review and explains the main dimensions and concepts of social responsibility in banks. The second part, was dedicated to the methodology followed to reach the papers goals including the model and the instrumentused to collect data. The third part is dealing with the discussion and results. Ultimately, comes the fourth part with the conclusions reached by this paper with some suggested future research directions.

\section{THEORETICAL FRAMEWORK}

In this section we will display some of the literature available about social responsibility and especially we will give attention to the concept and dimension in generalreviewing some studies applied in different organizations. Also, theconcept of social responsibility in banks is checked out with the main social participations contributed by those financial institutions.

\section{Social Responsibility : Concept and Dimensions}

The concept of social responsibility, as the term is most commonly used, belongs to businessfield. Normally, using the terminology "corporate social responsibility" is so common nowadays that it is standing for "CSR.". Even when social responsibility is mentioned on its own, a corporate dimension is intrinsic content for it .There are abundant studies about social responsibility in the literature, but not all of them are favorable of adopting social activities , they support Milton Friedman's idea that organizations' main goal is to achieve profits. But, almost the majority of those studies showed positive and big gains achieved by those companies adopting social responsibilities.

The concept was developed through decades, it meant philanthropic activities in its first beginning used, then it took legal, economic, and sustainable expectations of the society from business organizations.McWilliams et. al. stated that social responsibility is when an organization goes beyond making money and engages in actions that that results in social good, beyond the interests of the corporation which is beyond the interests of the corporation which is required by the law (McWilliams et. al. , 2006). Before that, European Commission defines CSR (2001), defined social responsibility as "a concept according to which companies voluntarily decide to contribute to the attainment of a better society and a cleaner environment" (European Commission Green Paper, 2001). So, the main goal of social responsibility adopting by firms is to improve society life and to protect the environment keeping it clean and sustained. 
International Journal of Business Management and Economic Review

Vol. 4, No. 04; 2021

ISSN: 2581-4664

The most important study of Carroll() introduced the well-known pyramid of social responsibility cited below, which indicated four types of social responsibility that gave a clear definition and broad content for this terminology.

Figure (1) : Carroll's Pyramid

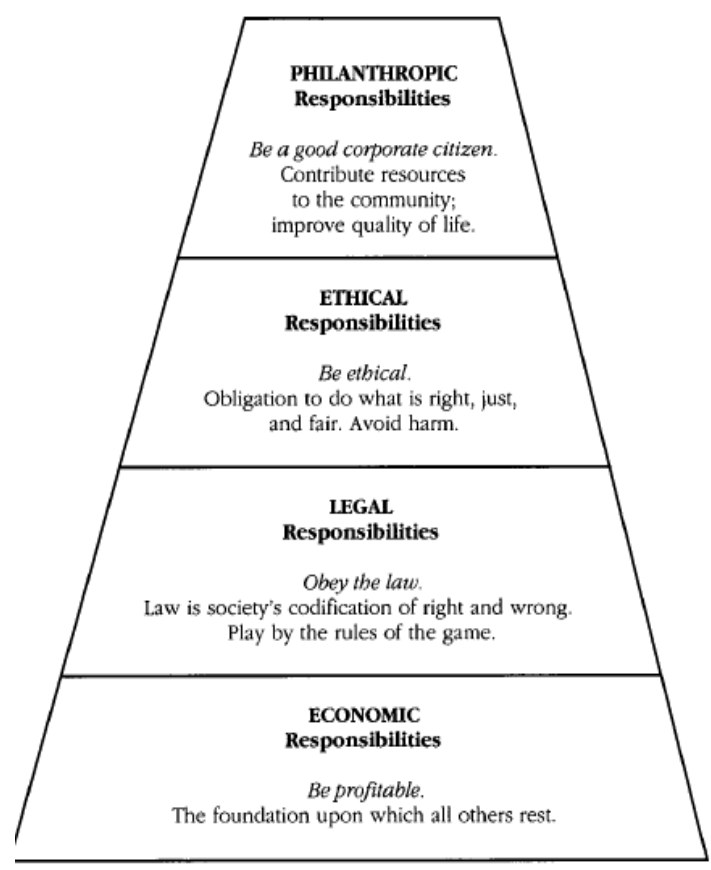

Source: Carroll, A., 1991, P. 42

Dahlstrom (2008), mentioned five dimensions when studied social responsibility definition. Thosedimensionsare:environmental,social, economic, stakeholder, and voluntariness dimension (Dahlsrud, 2008, P. 5). Discussing his results about the different definitions, he found that the lest dimension mentioned in all of them was the environmental one. He explained that because ". One explanation could be, as shown by Carroll's (1999) literature review, that the environmental dimension was not included in the early definitions, and this might have influenced current definitions to not include it either. Another and related reason is that the environmental dimension is not explicitly included in the definition, although it is considered to be a part of corporate social responsibility "(Dahlsrud, 2008, P. 8).

Rahman, (2011) studied many papers about social responsibility and summarized the findings in 10 major dimensions: 1. Obligation to the society 2. Stakeholders"e involvement 3. Improving the quality of life 4. Economic development 5. Ethical business practice

6. Law abiding 7. Voluntariness 8. Human rights 9. Protection of Environment 10. Transparency $\&$ accountability(Rahman, 2011, P. $173-174)$.

The studies mentioned above, give us a clear picture about social responsibility concept and its main dimensions. For this study, we will take four dimensions: environment, society, education, 


\section{International Journal of Business Management and Economic Review}

Vol. 4, No. 04; 2021

ISSN: 2581-4664

and culture and arts. So all the activities adopted by the Iraqi banks included in the framework of the four dimensions are examined and considered in its total as a social responsibility definition.

\section{Previous studies and literature review}

As we noticed before a lot of literature is available related social responsibility and its aspects and adoption in different sectors. Below we have chosen some of previous studies which are linked to the main point of this paper to be reviewed.

Marian Mocan et. al. (2015) explored"how the corporate social responsibility CSR) contributes to value creation in the banking industry, and during periods of financial instability".Knowing well the main components of socialresponsibility participatesin increasing the banks market share, profits achieved, and good advancement on the banks ranking. Their research wasfocused on the banking industry in Romania. They developed a model of SoCal responsibility that was representing Romanian banksduring an economic instability, they measure the impact of adopting social responsibility on some outcomes of the banks.The main result was help that the research offers to managers to focus on those social activities that could benefit customers and society in general. Our paper is a similar application in Tn the Iraqi environment.

Belaid Retta et. al. study (2009), tested the connection between

Social responsibility activities in the company'ssample of the study and organizational performance. The sample of 280 companies representing different economic sectors (seven of them are from banking and financial sector).Six dimensions of social responsibility related to community, environment, Employees, Investors, Customers and Supplies,representedthe independent variables, meanwhile the dependent variableswere:the financial performance, the corporate reputation, and the employees' commitment. A positive relationship was found between both variables. The importance of this study comes from its environment where it was carried out: an Arabic environment which has some communalities with the Iraqi one.

Also,Lindorff and Peck (2010), conducted an exploratory qualitative study in Australia to examine the social responsibility opinion nose leaders at thebiggest Australian financial firms.The authors used a semi-structured interviews theydid to give the ten leaders chosen from the largest financial institutions present their mental models of the institution, their vision aboutthe organizational responsibilities, their views about adopting social responsibility in the four components defined byCarroll,namely: economic, legal, ethical and philanthropic. Results indicated that the leaders confirmed that social responsibility practices benefit the organization financially and helped indeveloping sustainability, employees'satisfaction and performance, andalso,they believed to increase the organizations' legitimacy.

Almbarak, Z. et. al. (2018), in their study investigated the impact of social responsibility on the corporate image in the banking industry focusing on the principal aspects: economic, legal, ethical, and philanthropic. The sample was (144) banks clients, they were approached via questionnaire." The findings showed that customers perceive that social responsibility activities as a main element when dealing with banks. The corporate image is strengthened when banks adopt such activities, and positive and significant relationships were statistically found between CSR activities and corporate image. These activities differ in importance ay, it is perceived by banks' customers" (Al-Mubarak, Z., et. al.,2018, P. 1). The paper's value comes from being carried out in an Arabic country which has some similarities with the Iraqi one. 


\section{International Journal of Business Management and Economic Review}

Vol. 4, No. 04; 2021

ISSN: 2581-4664

In Scholten Study (2009), the author's aimwas to provide a framework to evaluate social responsibility at the international banking system. The author depends a sample of 32 international banks). The mostaspect of this study was that the balance sheet of each bank was100 billion euros or more.Only three banks, as maximum, are taken from each country; two conditions applied to include the bank in the study sample. The results showed significant differences among individual banks, countries and regions. The banks were evaluated on a 29 items scale grouped into four social responsibility dimensions: codes of ethics, sustainability reporting and environmental management systems, environmental management, responsible financial products, and socialconduct. Themain conclusion in the paper was thatthe social responsibility of the studied banks has improved significantly between 2000 and 2005 .

The McDonald and Rundle-Thiele Study (2007), explored the relationship between social responsibility adoption and bank clients' satisfaction. They depended a multi-method approach to examine the hypothesis formulated by authors, the sample consisted of 720 responses. The researchers tested the efficacy of their proposed model which contains 6 CSR initiative and 4 customer centric initiatives. The study put forward a series of propositions to guide future research that may assist researchers to redefine the stakeholder view by placing customers at the center of a network of stakeholders.

Margolis et. Al. (2009) conducted their investigation to test a 35-year research done by manyresearchers with the goal of detecting the relationship between social responsibility adoption and financial benefits achieved because of social responsibility activities inthe benefit of different stakeholders in the society. Authors used the meta analysis of 251 studies published between 1972 and 2007 on the same subject in different industries to discover that 59\% of those studies conducted a non-statistically significant link between CSR and CFP, meanwhile 28\% found a positive significant one. Only $2 \%$ of the studies discovered a negative Signiant linkage while $10 \%$ were not tested by the authors because of the sample size missing. All the studies reported using accounting or market measures, only 14 of them used both.

Vollono Study (2010) was carried out to explore the commercial merits of socially responsible business. Its main aim was to analyze if there is a positive connection between social responsibility and financial performance and to fin if the out the weather firms with more social responsibility activities are more profitable than those less socially responsible. Some marketing and accounting measures were used as financial performance indicators and also some other control variables like company size, year and type of industry. The outcome of this study was discovering a positive relationship between bothvariables.

In his paper about the social responsibility practices in the UAE , Al-Tamimi (2014) , investigated social responsibility practices of UAE banks using a developed modified questionnaire which consists of 18 questions about awareness of CSR, CSR dimensions, the most important issues of CSR, CSR instruments, stakeholders' engagement and co-operation, the community activities done by the banks, voluntary activities to alleviate climate' changes,social responsibility practices, organizational responsibility forsocial responsibility, payback of adopting social responsibility, public policy help for social responsibility and the link with the stakeholders. The conclusion indicated that the UAE banks are aware of the concept of social responsibility; they focus on paying much attention to mandatory social and environmental 


\section{International Journal of Business Management and Economic Review}

Vol. 4, No. 04; 2021

ISSN: 2581-4664

legislation and put less emphasis on the non-mandatory legislation; the banks patriate effectively "in supporting community activities, for instance through donations and sponsorship; the banks are not heavily involved in problems of climate change; the banks ensure equal access to their banking services for all women, irrespective of their marital status, race, etc.; the banks meet the mandatory legislation requirements related to CSR; and finally, the majority of the respondents (90 percent) indicated that it is important for their banks to inform stakeholdersabout their corporate social responsibility “(Al-Tamimi, 2014, P.91).

Garvila, R., (2019) in his dissertation with the aim ofexploring and understanding the reasons that motivates companies 'managements"to continue to engage their respective firms in implementing and promoting CSR, and the leadership strategies they employ to do it"(Gravila, 2019. P.12) The study was based on the purpose of answering the question: why do organizations continue to engage in corporate social responsibility programs? The author depended on themultiple casestudy approachwith the goal of to increasing the understanding about why and how certain large corporations persevere in the promotion and practicing of social responsibility activities."The sample consisted of leaders in 10 corporations, mainly in the telecommunications business, located on different continents (i.e., Europe and North America), recognized as sustainable promoters of CSR values. The findings indicated, through participants lived experiences, that CSR has significant and constructive influences to increase organization's visibility among stakeholders Regardless of the initial reasons when to implement a CSR program, the general opinion is that it manifestly contributed to company's wealth and assumed future positive and sustainable returns on investment"(Gravila, 2019 ,P.119-120). This study is considered one of the last and most important ones that demonstrate the positive eve social responsibility adoption.

\section{Previous studies benefits to this paper}

It is obvious for researchers in this field that a huge amount of literature is available on social responsibility and all its aspects, but we selected few of $r$, that there is abundant literature related to the different aspects of corporate social responsibility, but the author selected a limited number of the same to review in this source related to our research. The reason why the author did that because those studies are the closest to our study and they are the most helpful in the following areas:

1-They support in formulating the problem statement as most of them are treating the relationship between similar variables.

2-Gave the researcher obvious insight todevelop the hypothesis and to build the study's model.

3-Offering a good information source about all topics related to social responsibility, by this way the theoretical part is enriched and well developed.

4-All the studies included will be used to make comparisons to their results and the ones that will be concluded in this paper.

\section{Social Responsibility in banking Industry.}

Like other sectors, the banking industry in all over the world,have their social activities and contributes in solving many problems the society faces. Most of the banks achieve good profits and employ big number of people. The huge number of people that their life and work are influenced by the activities of financial institutions is increased gradually, because not only stakeholders and people who are working for them, but also the networks of other users who are 
International Journal of Business Management and Economic Review

Vol. 4, No. 04; 2021

ISSN: 2581-4664

getting use of their services. Banks adopted social responsibility have the aim of improving their corporate image through activities related to business and others which are not linked to same, as it is shown in figure ( ) developed by Lentner et. al. (2015).

Figure (2): Non-business and integrated into business activities

Source: Lentner et. al., 2015, P 100.

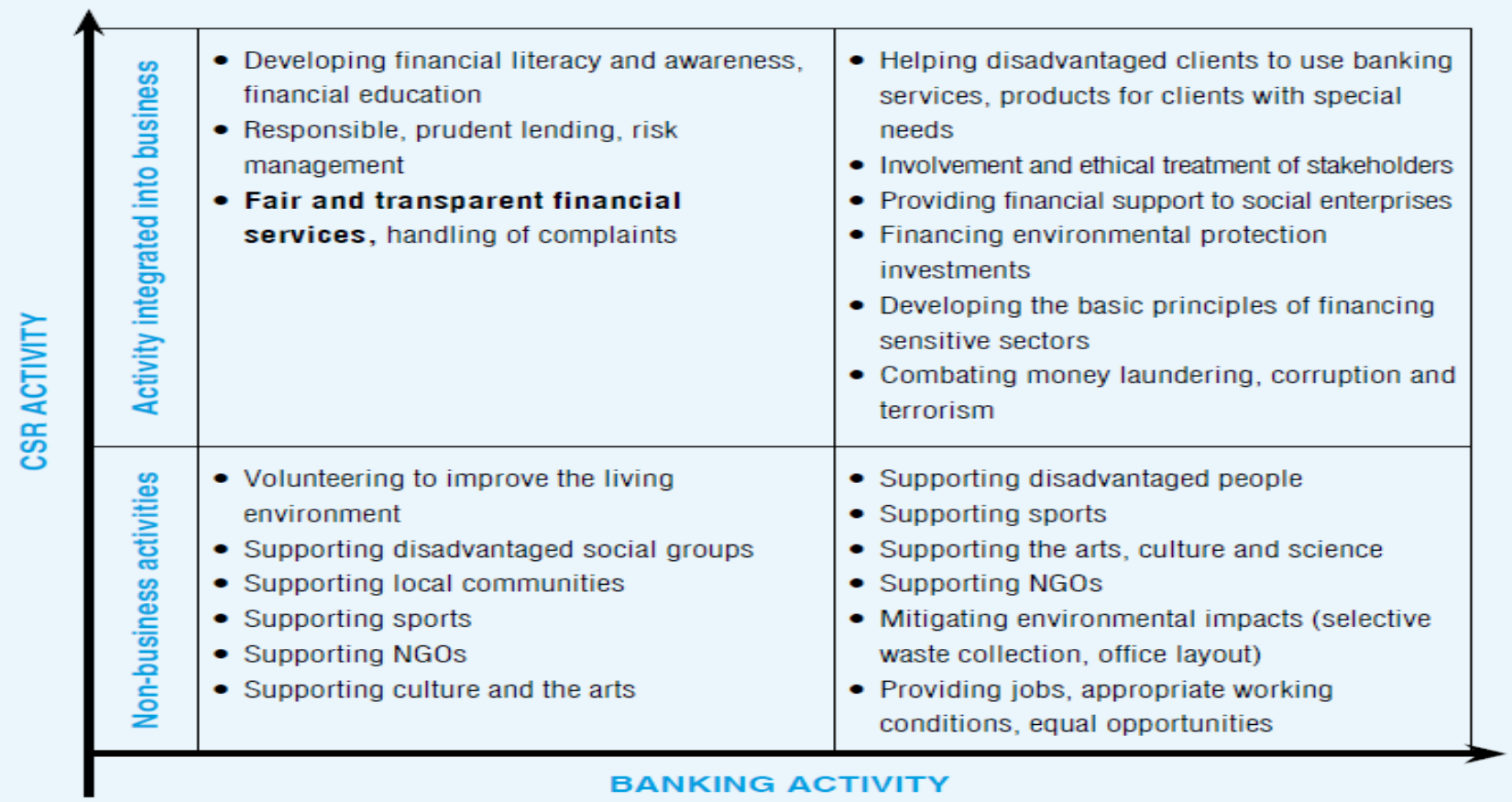

The world is passing hard time with Covid 19 pandemic which caused an economic instability, so the banking industry have to do its efforts to help in solving the problems resulting from this anormal situation. This is the most recent field that banks social activities covered, in addition to the many practices banks used to do for the environment, society, education, culture, arts, sports, and many others, as we can see in figure ( ), cited above.

As it is mentioned previously, Iraq passed into new era after 2003,emend us changes took place, one of them is in the banking system. It expanded in number of new private banks, new financial agencies, new role for the central bank, newservices, and much more. The sector is employing big number of people in private and public institutions. At the same time, banks are participating noticeably in social life, protecting environment, alleviating the pandemic effects, employing, supporting education, and improving community life. In this paper, the main social activities practiced by the banks in Iraqi governate of Wasit, that we take in consideration are:

1- Activities related to the environment protection and pollution reduction, rivers cleaning and maintaining, and other similar activities.

2- Social practices linked to society like women empowerment, senior people life improvement, youth training programs,entrepreneurship training and courses, and encouraging volunteerism to serve the society.

3- Social actions related to education and learning development and improvement. Banks offered many kinds of financial and in kind to help schools and universities to improve 


\section{International Journal of Business Management and Economic Review}

Vol. 4, No. 04; 2021

ISSN: 2581-4664

their infrastructures, financing training courses to improve teachingskills, and to develop their libraries.

4- Activities that backculture and arts, in form of financing conferences and celebrations, supporting the maintenance of all the cultural symbols in the governate of Wasit, and encouraging artists to and literals to publish their cultural production.

The complete list of the statements that describe those activities is found in Appendix ().

\section{RESEARCH METHODOLOGY}

\subsection{Problem Statement}

In Iraq there was unprecedented and huge expansion in the banking system) because of theeconomic, social, and cultural changes after the 2003 big change that took place. Many new banks financial institutions opened and started a revolutionary transforming in Iraqi economy. They practiced many social activities, that was something new and welcomed by society, as the social activities improved different aspects of people's life. So, how the adopting of social responsibility by public and private banks in Wasitgovernate impacts the banks outcomes?

\subsection{Research 's Purpose and goals}

This paper's main purpose is to explore the impact of social activities (environmental, Society, education, and culture and arts) practiced by Iraqi public and private banks on its different outcomes (government and owners, employees, services offered, and bank reputation). The study goals are defending in the light of the main purpose mentionedabove, they could be summarized in the following:

1- Describing the public and private banks' social activitiesdone.

2- Reviewing some definitions and dimensions in the literature review part related to social responsibility.

3- Testing the relationship between the social responsibility adopted by the banks and the outcomes improvement achieved by the same.

\subsection{Questions of the research}

As this paper will test the linkage between social responsibility and the outcomes improvement in Iraqi banks, we will state thequestion related to the point of the research of the same as follows:

Is the adoption of social responsibility by Iraqi public and private banks (banks (toward stockholders, stockholders, local community, environment, government, employees, customers) affects positively the organizational financial environmental, society, education, and cultural and arts responsibility impacts positively the outcomes government and owners' gains, employees' satisfaction, better services, and bank reputation?

\subsection{Model Conceptualization}

To address these questions that are based on the author expectations that a positive relationship exists between social responsibility adoption( independent variables ) by the Iraqi public and private banks and the outcomes improvements of the same ( dependent variables ), this 
International Journal of Business Management and Economic Review

Vol. 4, No. 04; 2021

ISSN: 2581-4664

paperstudies and examens a conceptual model shown in figure ( )..

Independent Variable

Social responsibility

adopted by bank

Environmental responsibility

Responsibility toward society

Education and learning

Culture and arts
Dependent Variable

Outcomes Improvements

Government and owners

Employees' satisfaction

Services offered by the bank

Bank reputation

Figure (3): The research model.

\subsection{The study hypothesis}

The proposition of the actual paper will be formulated as "The social responsibility toward stakeholders adopted by Iraqi public and private banks (toward environment, society, education and learning, and culture and arts)is positively impacted their outcomes (related to government and owners, employee satisfaction, services offered by the banks, and bank reputation)".

\subsection{Study sample and Instrument}

To achieve the goal of this study, the author chose a sample of Iraqi banks working in Wasit governate four banks, two of them are public (Ultrafidian and lashed banks), the others are private (Economy Private and Baghdad Private banks). Some 50 employees were selected randomly to answer the questionnaire that was developed depending, in part, on the study of Marian Mocan (2015) (Appendix 1). The statements representing the independent variable Q1Q16, and the statements related to the dependent variable continue from Q17 to Q32, so each sub-variable is measured by four statements. The Cronbach alpha was 0.789 which is accepted according to statistical measures, the statements were assessed with 5 Likert type scales.

\section{EMPIRICAL STUDY AND RESULTS ANALYSIS}

This section is dedicatedreview the resultsconcluded after analyzing data and the hypothesis testing, and discission.

\subsection{Data analysis and discussion}

With the aim of reviewingthe answers of the study sample employeeslinked to the sub variables included in the questionnaire, the mean, standard deviation, percentage, and general sample direction in favor of the statements, the following wereused:

1.The mean, in order to find the extent to which the answers of the study sample members are high or low for each of the study dimension.

2. Standard Deviation: to identify how fairs the deviation of the sample answers of the study members for each statement from its arithmetic mean, and it is noted that the standard deviation shows the dispersion in the answers of the study members to the statements along with the main axes, the closer its value to zero the more concentrated the answers and decreased scattered between scale.

3. Counting the range, which in this case is (the largest value - the smallest value), in the fivepoint Likert scale, i.e. $(5-1=4)$.

4- Then the class length is determined by (dividing the range by the number of Likert scale 
points), i.e. $(4 / 5=0.80)$.

5. After that, the length of the classis added to the smallest value in the scale, (in our case is 1) to get the upper bound of the class (strongly disagree) and by the same wayobtain the lower and upper limits of all the other classes, and they will be as follows:

6. Any mean value which isfound between $(1-1,79)$, is belongingto the class (strongly disagree), so it is less than $(20 \%)$.

7. Any mean whose value is located between (1.80 to 2.59) is classified in the class (do not agree), soit represents a percentage between $(21 \%)$ and $(40 \%)$.

8.The mean whose value is greater than 2.60 and less or Iguala 3.39) is assigned tothe (neutral) class, sothis is put between $(41 \%)$ and $(60 \%)$.

9.Any mean whose value is greater than (3.40 and less thanor equal to 4.19$)$ is classified in the class (agree), soit is between $(61 \%)$ and $(80 \%)$.

10. Any mean greater than (4.20 and less or equal to 5) is classified in the class (strongly agree),so itforms more than (81\%). As shown in Table No. ().

Table (1): The scale and measures used.

\begin{tabular}{|c|c|c|c|c|c|}
\hline Scale points & 1 & 2 & 3 & 4 & 5 \\
\hline Ratings & $\begin{array}{l}\text { Strongly } \\
\text { Disagree }\end{array}$ & Disagree & Neutral & Agree & $\begin{array}{l}\text { Strongly } \\
\text { agree }\end{array}$ \\
\hline Range & $1-1.79$ & $1.80-2.59$ & $2.60-3.39$ & 3.40-4.19 & $4.20-5.0$ \\
\hline $\begin{array}{l}\text { Accumulated } \\
\text { Percentage }\end{array}$ & $1 \%-20 \%$ & $\begin{array}{l}21 \% \\
40 \% \\
\end{array}$ & $41 \%-60 \%$ & $61 \%-80 \%$ & $81 \%-100 \%$ \\
\hline
\end{tabular}

First:data related to the independent variable (social responsibility adoption by public and private Iraqi banks) are shown in table (1). Those numbers are the average of each sub-variable measured by four statements each (the detailed result for each statement appeared in appendix (2).

Table (2):Main indicators of the independent variable.

\begin{tabular}{|llllll|}
\hline Dimension & $\begin{array}{l}\text { Sample } \\
\text { size }\end{array}$ & Mean & S. Deviation & Percentage & Direction \\
Environment & 50 & 3.67 & 0.77 & $73.4 \%$ & Agree \\
Society & 50 & 3.42 & 0.84 & $68.4 \%$ & Agree \\
Education & 50 & 3.65 & 0.79 & $73 \%$ & Agree \\
Culture & 50 & 3.50 & 0.86 & $70 \%$ & Agree \\
\hline
\end{tabular}

1- Social responsibility toward environment: as it is seen in the above table, average reached (3.67), which is greater than (3.50) and less than (4.19), this means that the sample members are in agreement with this dimension, as the banks take into account the environmental concerns.To identify the extent of the deviation of the individuals' responses to this dimension from its arithmetic mean, it is noticed that the standard deviation is (0.77), means which that it is less dispersal and more homogeneous, and the percentage is $(73.4 \%)$, which means that the sample trend is towards (agree). 
International Journal of Business Management and Economic Review

Vol. 4, No. 04; 2021

ISSN: 2581-4664

2.Social responsibility toward society: arithmetic average is (3.42), so it is higher than (3.40) and lower than (4.19), this indicates that the sample members agree with this dimension (taking in consideration the society social needs). But it is of importance mentioning here that the answers for two statements ( 6 and 8) related to supporting women healthcare and sports got neutral answer .This is could be understood observing the standard deviation which is (0.84), meaning that it is less dispersal and more homogeneous, and the percentage is (68.4\%), which means that the sample trend is towards (agree), but comparing it with the first dimension . we conclude that there is less agreement on this dimension ( lower mean and higher standard deviation ).

3. Social responsibility toward education and learning: the data shows that as the mean of the four statements of this dimensionis (3.65), which is greater than (3.40) and less than (4.19), for this it indicates that the sample members look in agreement withthat the bankspay attention to education and learning improvement.The deviation of individuals' responses to the statements less dispersal and it looks more homogeneous, and the percentage is (73\%), which means that the sample members are showing direction to (agree).

4.Social responsibility toward culture and arts: on this dimension we see that the mean is (3.5), it is higher than (3.40) but it islower than (4.19), which marks that the sample tends to bein agreement about the banks' interest in promoting culture and arts. For this dimension one statement out of four got neutral answer (taking culture and arts when formulating banks' future strategies).It is noted that the standard deviation reached (0.86), meaning that it is less dispersal and more homogeneous, and the percentage is $(70 \%)$, so that meansthat the sample members trend towards agreeing about this dimension.

Second:data related to the independent variable (public and private Iraqi banks 'outcomesimprovements) are shown in table (2). Those numbers are the average of each subvariable measured by four statements each, the detailed result for each statement appeared in appendix (3).

Table (3): The main indicators of the dependent variable

$\begin{array}{llllll}\text { Improvement } & \begin{array}{l}\text { Sample } \\ \text { size }\end{array} & \text { Mean } & \begin{array}{l}\text { S. } \\ \text { Deviation }\end{array} & \text { Percentage } & \text { Direction } \\ \text { Government } & 50 & 3.44 & 0.77 & 68.8 \% & \text { Agree } \\ \text { Employees } & 50 & 3.59 & 0.79 & 71.4 \% & \text { Agree } \\ \text { Services } & 50 & 3.53 & 0.82 & 70.6 \% & \text { Agree } \\ \text { Reputation } & 50 & 3.61 & 0.82 & 72.2 \% & \text { Agree }\end{array}$

1.Governement and owners:tab (1), as the le shows the mean of the answers assigned to the four statements related to the improvements of this sub-variable is (3.44), it is greater than (3.40) and lower than (4.19), which indicates that the sample looks at (agree), even there are two statements out of four were answered neutral. Those are related with the bank' growth and the job opportunities creation. The standard deviation is of 0.77 , and the percentage is $68 \%$, this means that it is located in the range of agreeing about the improvements achieved for the government as the owner of the public banks, and for the private bank's owners.

2.Employees' outcomes improvements:from the table (2) we can see that the average is (3.59) 


\section{International Journal of Business Management and Economic Review}

Vol. 4, No. 04; 2021

ISSN: 2581-4664

for this dependent sub-variable, it is greater than (3.39) and lower than (4.19), which indicates that the sample looks at agreeing with that there is improvement linked to the employees gains except one statement related to the job satisfaction which was answered as neutral.It is noted that the standard deviation reached (0.79), so we can consider it as less dispersal and more homogeneous, the percentage is $(71.4 \%)$, so the trend is towards (agree).

3.Services provided by the banks: all the statement here in this dimension representing the improvements done on the services offered by the banks were answered positively, so the agreement is accomplished showing a mean of (3.53) and a standard deviation of (0.82). The percentage reaches $(70.6 \%)$. It is of significance that the sample agrees that the service is advancing and showing amelioration with progress in improving quality, more accordance and better procedures in serving banks' customers.

4. Banks' reputation: theanalysis of the fourth sub-variable displays that its mean is (3.61), which is greater than (2.60) and less than (3.39), this shows that the sample considers an (agree) view of about the reputation achieved in those banks.But tow statements were answered in a neutral way (29 and 32), both are about the reputation and the presence in the media (appendix3). In total, the standard deviation registered (0.82), which means minimaldispersal and extra homogeneous, the percentage is $(72.2 \%)$, which gives us that the sample trend of agreement about those improvements.

\section{CONCLUSIONS AND RECOMMENDATIONS}

The main conclusions that this paper reached after we checked all the dimensions and its subvariables for the independent and the dependent variables are as follows:

1-The Iraqi public and private banks adoption of social responsibility resulted in positive consequences and affected banks performance in a favorable way.

2-Practicing social activities toward the environment and reducing pollution affect the banks outcome positively in what refers to government and owners, employees, the offered services, and the bank reputation.

3-Adopting social responsibility toward society in form of taking care of seniors, womenand youth, entrepreneurs, and encouraging volunteerism is one factor that improves the banks outcomes, meliorating services quality, work accordance, and making procedures more effective and less time consuming.

4- The social activities done by the banks helping education and learning institutions, gave its results affecting positively the outcomes on all the four dimensions.

5-Cultural and arts support by the banks included in the research sample showed good improvements in the bank's performance for the all four dimensions of the dependent variable, in what refers to work quality and reputation in the society.

6-Some of the statements did not achieve the agreement of the sample members, the got a neutral evaluation, so more research could be done to see what are the reasons and how that could be corrected.

7-Respect to the methodology followed in this research,the focusonly took in account some employees points of view in a limited number of banks sample members. The paper's final conclusion may beinadequate for drawing the total picture of banks reality. As, recommendations for future investigation and research we advisethat the future research to be conducted both qualitatively and qualitatively with the aim to get deep and more information particularly at the 


\section{International Journal of Business Management and Economic Review}

Vol. 4, No. 04; 2021

ISSN: 2581-4664

management level.In addition, the future research should build or develop the models and test all specific dimensions statistically for more accurate results.

\section{REFERENCES}

Al Mubarak, Zainab et. al.," Impact of corporate social responsibility on bank's corporate image ", Social Responsibility Journal,November, 2018https://doi.org/10.1108/SRJ-01-2018-0015 Hassan Al-Tamimi, Hussein A., Corporate Social Responsibility Practices of UAE Banks (2014). Global Journal of Business Research, v. 8 (3) p. 91-108, 2014, Available at SSRN: https://ssrn.com/abstract=2451207

Belaid, Rettab et. al.Editors," CSR and Corporate Performance with Special Reference to the Middle East", in"practicing CSR in the Middle East" Ed. Palgrave McMillan, London,2019, P. 101-11

Carroll, A.," The Pyramid of Corporate Social responsibility: Toward the Moral Management of the Organizational Stakeholder "BusinessHorizons, July-August, 1991. P. 39 - 48

Dalshurd, A., "How Corporate Social Responsibility is Defined: An Analysis of 37 Definitions"Corporate Social Responsibility and Environmental Management, 15,2008, P. 1-13. https://doi.org/10.1002/csr.132

European Commission, Green Paper," Promoting a European framework for corporate social responsibility", 2001, Brussels: COM. 366.

Gavrila, Radu-Marius, "Factors Leading Corporations to Continue to Engage in Corporate Social Responsibility Initiatives" (2019). Walden Dissertations and Doctoral Studies. 6897.https://scholarworks.waldenu.edu/dissertations/6897

Lentner, Csaba et. el., “Corporate Social Responsibility in the Banking Sector”, Public Finance Quarterly, January 2015, PP. 95-103.

Lindorff, Margaret and James Peck, "Exploring Australian Financial Leaders' views of Corporate Social Responsibility", Journal of Management and Organization, Vol. 16, No 1, 2010. P.48-65.14.

Margolis, Joshua D. and Elfenbein, Hillary Anger and Walsh, James P., Does it Pay to Be Good...And does it Matter? A Meta-Analysis of the Relationship between Corporate Social and Financial Performance (March 1, 2009). Available at SSRN: https://ssrn.com/abstract=1866371 or http://dx.doi.org/10.2139/ssrn.1866371

McDonald, L.M. and Rundle-Thiele, S. (2008), "Corporate social responsibility and bank customer satisfaction: A research agenda", International Journal of Bank Marketing, Vol. 26 No. 3, pp. 170-182. https://doi.org/10.1108/02652320810864643

McWilliams, A., Siegel, D. S., \& Wright, P. M. (2006). Corporate social responsibility: Strategic implications*. Journal of management studies, 43(1), 1-18.https://doi.org/10.1111/j.14676486.2006.00580.x

Mandina, S., Maravir, C. and Masere, V. (2014), "Effectiveness of Corporate Social Responsibility in Enhancing Company Image", European Journal of Business and Management, Vol. 6 No. 5, pp. 46-61.

Rahman, S., "Evaluation of Definitions: Ten Dimensions of Corporate Social Responsibility 
International Journal of Business Management and Economic Review

Vol. 4, No. 04; 2021

ISSN: 2581-4664

"World Review of Business Research, Vol. 1. No. 1. March 2011. Pp. 166 - 176.

Scholtens, B. Corporate Social Responsibility in the International Banking Industry. J Bus Ethics 86, 159-175 (2009). https://doi.org/10.1007/s10551-008-9841-x

Soana, MG. The Relationship Between Corporate Social Performance and Corporate Financial Performance in the Banking Sector. J Bus Ethics 104, 133 (2011). https://doi.org/10.1007/s10551-011-0894-x

Susilova, Vendula, "Critical Evaluation of a Concrete MNE'S CSR as a Copetitiveness Factor “, Vollono, Robert j.," Doing Well by Doing Good: The empirical Relationship Between CorporateSocial Responsibility and Financial performance ", A master Tesis Submitted to the faculty of The Graduate School and Sciences of Georgetonn University, Washington ,2010.http://hdl.handle.net/10822/553949 
International Journal of Business Management and Economic Review

Vol. 4, No. 04; 2021

ISSN: 2581-4664

Appendix(1):The statements used to measure the independent and independent variables in the questionnaire

(TheLikert five-point scale is depended).

I. Independent Variable: Social Responsibility Adoption by Banks.

*Environmental Responsibility

1-The bank supports the recycling activities and encourage companies to do that.

2-Our bank participates in trees planting campaign.

3-Protecting the environment and on are a priority to our bank.

4-Maintaining and cleaning rivers and the creeks in the city is very important to our bank.

*The Society

5-The bank supports and protect senior people category in the society.

6-our bank contributes effectively to the women healthcare and sport activities for young people.

7-Our bank encourages the development of entrepreneurs and entrepreneurship

8 -Volunteering to serve the society is well encouraged by the bank.

*Education and Learning

9-The bank offers grants to gifted students.

10-Our bank supports many schools and universities activities (libraries, lectures...).

11-The bank sponsors different programs of financial education and works on books and magazines helping people to understand and practice investment.

12-The bank contributes into developing the teaching staff through training courses.

\section{*Culture and Arts}

13-The bank promotes and supports cultural and artistic activities in form of conferences, lectures, and celebrations.

14-Our bank encourages literal, artistic, and cultural activities like offering monitorial support to publish.

15-The bank sponsors TV cultural and economic programs.

16-When formulating future strategies, the bank takes into account the Iraqi culture and art.

\section{Dependent Variables:Banks' Outcomesimprovement}

\section{*The Government and Owners}

17-The bank is achieving more profits than before.

18-Our bank shows higher growth than before.

19-The paidtaxes to the government by the bank are more than before.

20-More jobs have been created by the bank are more.

* Employees

21-The bank's employees are feeling more motivated than before.

22-Higher job satisfaction feelings by bank's employees arenoticed.

23-Emloyees' salaries and wages increased more than before.

24-The bank is offering mor training and development opportunities.

*Services Offered

25-The different services offered by the bank are more accurate and faster than before.

26-There is a noticeable increase in the new services presented by the bank.

27-There is big improvement in the services' quality than before.

28-The bank is reducing and improving the services procedures to make customers happier. 
International Journal of Business Management and Economic Review

Vol. 4, No. 04; 2021

ISSN: 2581-4664

\section{*Bank Reputation}

29-The bank's reputation has been improved clearly in the society.

30-It is noticed that more clients are dealing with the bank than before.

31-The bank got bigger market share than its competitors.

32-There is bigger presence in the media for our bank.

Appendix (2): The detailed answers for the statements measuring the independent variable

\begin{tabular}{|c|c|c|c|c|c|c|c|c|c|c|}
\hline $\begin{array}{l}\text { Statem } \\
\text { ent }\end{array}$ & $\begin{array}{l}\text { Stron } \\
\text { gly } \\
\text { Agree }\end{array}$ & $\begin{array}{l}\text { Agr } \\
\text { ee }\end{array}$ & $\begin{array}{l}\text { Neutr } \\
\text { al }\end{array}$ & $\begin{array}{l}\text { Do } \\
\text { not } \\
\text { Agr } \\
\text { ee }\end{array}$ & $\begin{array}{l}\text { Stron } \\
\text { gly Do } \\
\text { not } \\
\text { Agree }\end{array}$ & $\begin{array}{l}\text { Samp } \\
\text { le } \\
\text { Size }\end{array}$ & $\begin{array}{l}\text { Mea } \\
\text { n }\end{array}$ & $\begin{array}{l}\text { Standa } \\
\text { rd } \\
\text { Deviati } \\
\text { on }\end{array}$ & $\begin{array}{l}\text { Percent } \\
\text { age }\end{array}$ & $\begin{array}{l}\text { Directi } \\
\text { on }\end{array}$ \\
\hline 1 & 5 & 29 & 5 & 6 & 5 & 50 & 3.83 & 0.70 & $76.6 \%$ & Agree \\
\hline 2 & 4 & 26 & 9 & 6 & 5 & 50 & 3.63 & 0.72 & $72.6 \%$ & Agree \\
\hline 3 & 4 & 25 & 10 & 6 & 5 & 50 & 3.59 & 0.76 & $71.8 \%$ & Agree \\
\hline 4 & 5 & 21 & 15 & 4 & 5 & 50 & 3.51 & 0.74 & $70.2 \%$ & Agree \\
\hline 5 & 5 & 21 & 13 & 6 & 5 & 50 & 3.49 & 0.77 & $69.8 \%$ & Agree \\
\hline 6 & 5 & 18 & 12 & 10 & 5 & 50 & 3.29 & 0.89 & $65.8 \%$ & $\begin{array}{l}\text { Neutra } \\
\text { l }\end{array}$ \\
\hline 7 & 5 & 24 & 10 & 6 & 5 & 50 & 3.54 & 0.80 & $70.8 \%$ & Agree \\
\hline 8 & 5 & 18 & 12 & 10 & 5 & 50 & 3.32 & 0.87 & $66.4 \%$ & $\begin{array}{l}\text { Neutra } \\
\text { l }\end{array}$ \\
\hline 9 & 5 & 20 & 11 & 9 & 5 & 50 & 3.49 & 0.89 & $69.8 \%$ & Agree \\
\hline 10 & 4 & 26 & 9 & 6 & 5 & 50 & 3.78 & 0.68 & $75.6 \%$ & Agree \\
\hline 11 & 5 & 23 & 12 & 5 & 5 & 50 & 3.76 & 0.73 & $75.2 \%$ & Agree \\
\hline 12 & 5 & 24 & 10 & 6 & 5 & 50 & 3.76 & 0.76 & $75.2 \%$ & Agree \\
\hline 13 & 5 & 26 & 10 & 4 & 5 & 50 & 3.76 & 0.85 & $75.2 \%$ & Agree \\
\hline 14 & 3 & 29 & 7 & 5 & 6 & 50 & 3.73 & 0.77 & $74.6 \%$ & Agree \\
\hline 15 & 4 & 23 & 13 & 4 & 6 & 50 & 3.51 & 0.70 & $70.2 \%$ & Agree \\
\hline 16 & 3 & 20 & 11 & 11 & 5 & 50 & 3.10 & 1.01 & $62 \%$ & $\begin{array}{l}\text { Neutra } \\
\text { I }\end{array}$ \\
\hline
\end{tabular}


International Journal of Business Management and Economic Review

Vol. 4, No. 04; 2021

ISSN: 2581-4664

Appendix (3):The detailed answers for the statements measuring the dependent variable

\begin{tabular}{|c|c|c|c|c|c|c|c|c|c|c|}
\hline $\begin{array}{l}\text { Statem } \\
\text { ent }\end{array}$ & $\begin{array}{l}\text { Stron } \\
\text { gly } \\
\text { Agree }\end{array}$ & $\begin{array}{l}\text { Agr } \\
\text { ee }\end{array}$ & $\begin{array}{l}\text { Neutr } \\
\text { al }\end{array}$ & $\begin{array}{l}\text { Do } \\
\text { not } \\
\text { Agr } \\
\text { ee }\end{array}$ & $\begin{array}{l}\text { Stron } \\
\text { gly Do } \\
\text { not } \\
\text { Agree }\end{array}$ & $\begin{array}{l}\text { Samp } \\
\text { le } \\
\text { Size }\end{array}$ & $\begin{array}{l}\text { Mea } \\
\text { n }\end{array}$ & $\begin{array}{l}\text { Standa } \\
\text { rd } \\
\text { Deviati } \\
\text { on }\end{array}$ & $\begin{array}{l}\text { Percent } \\
\text { age }\end{array}$ & $\begin{array}{l}\text { Directi } \\
\text { on }\end{array}$ \\
\hline 17 & 2 & 20 & 15 & 8 & 5 & 50 & 3.51 & 0.70 & $70.2 \%$ & Agree \\
\hline 18 & 4 & 20 & 16 & 5 & 5 & 50 & 3.39 & 0.73 & $67.8 \%$ & $\begin{array}{l}\text { Neutra } \\
\text { l }\end{array}$ \\
\hline 19 & 5 & 26 & 8 & 5 & 6 & 50 & 3.59 & 0.73 & $71.8 \%$ & Agree \\
\hline 20 & 6 & 14 & 17 & 7 & 6 & 50 & 3.24 & 0.82 & $64.8 \%$ & $\begin{array}{l}\text { Neutra } \\
\text { l }\end{array}$ \\
\hline 21 & 5 & 21 & 13 & 5 & 6 & 50 & 3.49 & 0.77 & $69.8 \%$ & Agree \\
\hline 22 & 5 & 18 & 11 & 10 & 6 & 50 & 3.29 & 0.89 & $65.8 \%$ & $\begin{array}{l}\text { Neutra } \\
\text { l }\end{array}$ \\
\hline 23 & 4 & 29 & 9 & 3 & 5 & 50 & 3.83 & 0.70 & $70.8 \%$ & Agree \\
\hline 24 & 5 & 26 & 10 & 4 & 5 & 50 & 3.63 & 0.72 & $66.4 \%$ & Agree \\
\hline 25 & 5 & 21 & 15 & 4 & 5 & 50 & 3.51 & 0.74 & $69.8 \%$ & Agree \\
\hline 26 & 6 & 26 & 16 & 4 & 5 & 50 & 3.78 & 0.68 & $75.6 \%$ & Agree \\
\hline 27 & 5 & 29 & 8 & 5 & 6 & 50 & 3.73 & 0.77 & $75.2 \%$ & Agree \\
\hline 28 & 4 & 23 & 17 & 4 & 6 & 50 & 3.51 & 0.70 & $75.2 \%$ & Agree \\
\hline 29 & 4 & 22 & 13 & 7 & 5 & 50 & 3.39 & 0.79 & $67.8 \%$ & $\begin{array}{l}\text { Neutra } \\
1\end{array}$ \\
\hline 30 & 5 & 23 & 11 & 2 & 5 & 50 & 3.76 & 0.73 & $74.6 \%$ & Agree \\
\hline 31 & 5 & 24 & 9 & 6 & 6 & 50 & 3.76 & 0.76 & $70.2 \%$ & Agree \\
\hline 32 & 4 & 17 & 10 & 5 & 6 & 50 & 3.39 & 0.88 & $67.8 \%$ & $\begin{array}{l}\text { Neutra } \\
\text { l }\end{array}$ \\
\hline
\end{tabular}

